Tadeusz BORYS 1

\title{
WYBRANE PROBLEMY METODOLOGII POMIARU NOWEGO PARADYGMATU ROZWOJU - POLSKIE DOŚWIADCZENIA
}

\begin{abstract}
Streszczenie
W artykule dokonano próby podsumowania dotychczasowych polskich doświadczeń w tworzeniu podstaw metodologii pomiaru nowego paradygmatu rozwoju, nazywanego w artykule rozwojem zintegrowanym. Przyjęto założenie, że konkretyzacja i pomiar rozwoju to pojęcia ściśle ze soba powiązane. Podstawą metodologiczną tworzenia zestawów wskaźników dla nowego paradygmatu rozwoju jest właśnie różnego typu operacjonalizacja. Służy ona monitorowaniu realizacji wielu dokumentów planistycznych, opracowywanych na różnych poziomach zarządzania rozwojem (lokalnym, regionalnym, krajowym itd.) przez określenie dla każdego poziomu uzgodnionego i dobrze określonego zestawu mierników. W artykule tym sformułowano odpowiedzi na następujące, ważne pytania. Jaka jest mapa drogowa polskich doświadczeń w pomiarze nowego paradygmatu rozwoju? Jakie jest odniesienie tej polskiej mapy do doświadczeń międzynarodowych i umownie wydzielonych etapów ewolucji podejścia do nowego paradygmatu? Jaki jest stan i główne problemy metodologiczne związane z pomiarem nowego paradygmatu? Co obecnie można uznać w tej metodologii za względnie ustabilizowane i jakie problemy można przyjać za nadal otwarte?
\end{abstract}

Słowa kluczowe: metodologia, paradygmat, pomiar, rozwój zintegrowany

\section{SELECTED PROBLEMS OF MEASUREMENT METHODOLOGY OF NEW DEVELOPMENT PARADIGM: POLISH EXPERIENCES}

\section{Summary}

The paper attempts to summarize the existing Polish experiences in creating the foundations of a methodology for measuring the new development paradigm, here referred to as integrated development. It was assumed that both the embodiment and measurement of development represent closely related terms. A methodological basis for the sets of measures for the new development paradigm is provided by various types of operationalization. They are used to monitor the implementation of numerous planning documents, prepared at different levels (local, regional, national etc.), by means of identifying sets of measures, agreed upon and well defined for each level. The paper offers answers to the following important questions: What is the road map of Polish experiences in measuring the new development paradigm? How does this Polish map relate to international experiences and conventionally distinguished stages of evolution in the approach to this paradigm? What is the status and major methodological problems related with the measurement of the new paradigm? What elements of the methodology can currently be considered relatively stable and which problems must be regarded as unresolved?

Key words: methodology, paradigm, measurement, integrated development

\footnotetext{
${ }^{1}$ prof. dr hab. Tadeusz Borys - Wydział Ekonomii, Zarządzania i Turystyki, Uniwersytet Ekonomiczny we Wrocławiu; e-mail: tadeusz.borys@ue.wroc.pl.
} 


\section{Wstęp}

Identyfikacja stanu i głównych problemów metodologicznych pomiaru nowego paradygmatu rozwoju to trudne zadanie, bowiem dorobek w tym zakresie jest ogromny, a jednocześnie nie zawsze spójny czy dostatecznie uporządkowany. Dotyczy on nie tylko podstaw pochodzących z nauk formalnych (matematyki, statystyki czy dziedzinowych nauk numerycznych - np.: ekonometrii, naukometrii czy psychometrii), ale dotyka także kluczowych problemów teorii rozwoju oraz pewnych subdyscyplin nauk filozoficznych, zwłaszcza aksjologii.

Należy zwrócić uwagę, że w tytule tego artykułu występuje, na razie dość enigmatyczna, kategoria „nowy paradygmat rozwoju”, a nie „rozwój zrównoważony”. Zostało to dalej szerzej uzasadnione w kontekście pewnej propozycji semantycznej, integrującej najważniejsze pozytywne cechy, które opisują istotę nowego paradygmatu rozwoju.

Warto również na wstępie podkreślić, że konkretyzacja i pomiar rozwoju to pojęcia ściśle ze sobą powiązane. Podstawą metodologiczną tworzenia zestawów wskaźników dla nowego paradygmatu rozwoju jest właśnie różnego typu operacjonalizacja. Służy ona monitorowaniu realizacji wielu dokumentów planistycznych (strategii, programów, polityk itp.) opracowywanych na różnych poziomach zarządzania rozwojem (lokalnym, regionalnym, krajowym itd.) przez określenie dla każdego poziomu uzgodnionego i dobrze określonego zestawu mierników.

W artykule tym główną uwagę skoncentrowano na dwóch powiązanych ze sobą grupach pytań.

1. Jaka jest mapa drogowa polskich doświadczeń w pomiarze nowego paradygmatu rozwoju? Jakie jest odniesienie tej polskiej mapy do doświadczeń międzynarodowych i umownie wydzielonych etapów ewolucji podejścia do nowego paradygmatu?

2. Jaki jest stan i główne problemy metodologiczne związane z pomiarem nowego paradygmatu? Co obecnie można uznać w tej metodologii za względnie ustabilizowane i jakie problemy można przyjąc za nadal otwarte?

Zawarte w tym artykule odpowiedzi na te pytania to próba weryfikacji hipotezy badawczej, zawartej w stwierdzeniu, że nowy paradygmat rozwoju jest już kategorią w dużym stopniu poddającą się różnym rodzajom operacjonalizacji, w tym operacjonalizacji wskaźnikowej.

\section{2. Światowe inspiracje polskich badań nad pomiarem nowego paradygmatu rozwoju}

Wyzwanie dotyczące tworzenia systemów wskaźników monitorujących wprowadzanie nowego paradygmatu rozwoju zostało podjęte przez środowiska twórcze już kilkadziesiąt lat temu i wiązało się głównie $\mathrm{z}$ dyskusją nad problemem mierzenia dobrobytu ekonomicznego i społecznego. W sensie historycznym dyskusja ta przechodziła kilka etapów, które miały miejsce głównie w XX wieku. 
1. Lata pięćdziesiąte to spory wokół problemów mierzenia bogactwa narodowego i systemów statystyki społeczno-ekonomicznej, które doprowadziły do wypracowania przez zespół R. Stone'a jednolitej metody liczenia dochodu narodowego we wszystkich krajach OECD i powstania standardowego systemu rachunków narodowych (System of National Account - SNA), charakteryzującego się zarówno szeregiem zalet, jak i wad z punktu widzenia uwzględniania środowiskowych kosztów rozwoju [W skaaźniki..., 1999, s. 13-14; Stone, 1956].

2. Lata sześćdziesiąte to kontrowersje przy wprowadzeniu do praktyki SNA i konkurencyjnego wobec SNA systemu MPS (Systemu Bilansów Materialnych - System of Material Product Balances). Dotyczyły one głównie braku dostatecznej poprawności w wewnętrznej konstrukcji stosowanych w ich ramach mierników, a także uznania GNP (Produktu Narodowego Brutto - Gross National Product) za niewłaściwy miernik dobrobytu. Coraz częściej pojawiała się krytyka dotychczasowej „filozofii rozwoju”, szczególnie wyeksponowana pod koniec lat sześćdziesiątych w raportach ONZ i w pierwszych latach siedemdziesiatych w raportach Klubu Rzymskiego². Badania te ukonstytuuowały pierwszy etap ewolucji podejścia do wyłaniających się zarysów nowego paradygmatu rozwoju. Etap ten można określić umownie mianem inspiracji. Objął on narodziny alternatywnych koncepcji rozwoju i próby ich pierwszych identyfikacji i sięgał w dużym stopniu także lat siedemdziesiatych XX wieku. Pierwsze analizy tego etapu koncentrowały się na ustaleniu relacji pomiędzy człowiekiem i formami jego aktywności gospodarczej a środowiskiem przyrodniczym - pojawił się w tym okresie pierwszy zarys koncepcji społeczeństwa poszanowania zasobów [Borys, Czaja, 2009, s. 51-75].

3. Lata siedemdziesiąte i osiemdziesiąte to okres bardzo dynamicznego rozwoju metodologii pomiaru rozwoju, nie tylko w wymiarze ekonomicznym, a także ogromny wzrost zainteresowania praktycznym wykorzystaniem dorobku taksonometrii i wielowymiarowej analizy porównawczej (WAP) ${ }^{3}$, [np.: Hellwig, Kania-Gospodarowicz, 1975]. Jednak zauważa się coraz wyraźniej funkcjonowanie obok siebie, często niezależnie, dwóch nurtów analizy wskaźnikowej, a mianowicie - aksjologicznego nurtu konstrukcji wskaźników konkretyzujących coraz śmielej nowy paradygmat rozwoju i dominującego jeszcze w tym czasie nurtu drugiego, neutralnego aksjologicznie, wyraźnie niedoceniającego kryteriów merytorycznych doboru cech diagnostycznych, które powinny wynikać wprost z dekompozycji wskaźnikowej określonej koncepcji rozwoju. Ten drugi podokres, obejmujacy lata osiemdziesiąte, to kolejny etap rozwoju podstaw teoretycznych, w tym konkretyzacji wskaźnikowej nowego para-

\footnotetext{
2 Należały do nich: raport U'Thanta pt.: Cžtowiek i Środowisko z 1969 roku i dwa raporty Klubu Rzymskiego z 1972 i 1974 roku.

${ }^{3}$ Okazały się one wartościowe zwłaszcza w ocenie rozwoju kraju i innych jednostek terytorialnych. Znalazło to swój wyraz nie tylko w wielu próbach szacowania tego rozwoju, ale także w bardzo bogatym dorobku teoretycznym, dotyczącym szczególnie: miar syntetycznych, wyboru cech istotnych i określania funkcji preferencji (ocen). Należy zwrócić uwagę, że przy dwóch ostatnich kwestiach przeważały kryteria formalne, np. przy wyborze cech - kryteria dostatecznej zmienności i nieskorelowania.
} 
dygmatu. Można go określić umownie etapem dojrzewania [Borys, Czaja, 2009, s. 51-75]. Charakteryzowały go intensywne prace nad nadaniem konkretnej treści tej koncepcji rozwoju, których ważnym podsumowaniem pod koniec lat osiemdziesiątych było przygotowanie raportu Brundtland pt:: Our Common Future [Our Common..., 1987], w którym sformułowano, fundamentalną dla nowego paradygmatu rozwoju, zasadę sprawiedliwości międzypokoleniowej w dostępie do środowiska przyrodniczego. Eksponowała ona cechę samopodtrzymywania tego dostępu przez kolejne pokolenia jako kluczowy element jakości życia tych pokoleń. Tym samym wprowadzono do obiegu międzynarodowego kategorię Sustainable Development.

4. Pierwsza połowa lat dziewięćdziesiątych to prawdziwy przełom w metodologii badań nad pomiarem nowego paradygmatu rozwoju - kreowały go głównie inspiracje United Nations Commission on Sustainable Development (UNCSD) i efekty Szczytu Ziemi w Rio de Janerio w 1992 roku. To okres licznych inicjatyw wskaźnikowych: UNDP, UNEP, UNECE, FAO oraz Banku Światowego i IUCN, a przede wszystkim OECD i agend Unii Europejskiej (w tym Europejskiej Agencji do spraw Ochrony Środowiska - EEA), [Wskaźniki..., 2005, s. 16]. W efekcie pojawiła się nowa grupa mierników, określanych mianem wskaźników Sustainable Development. Związane to było z operacjonalizacja tej kategorii rozwoju i dostrzeżeniem w koncepcjach rozwoju społeczno-gospodarczego ekologicznie zdeterminowanych możliwości tego rozwoju, czyli funkcji systemu ekologicznego, rozważanych w kontekście wprowadzonej przez D. Pearce’a i R. Turnera koncepcji gospodarki okrężnej, ściśle powiązanej w teorii nowego paradygmatu rozwoju z kategorią zasobu naturalnego ${ }^{4}$. Etap ten wyróżniał się gwałtowną intensyfikacją zainteresowań nową koncepcją rozwoju, szczególnie ujawniał swoje cechy w okresie poprzedzającym I Szczyt Ziemi i w pierwszych latach po jego zakończeniu. Można go nazwać etapem zauroczenia czy fascynacji nowym paradygmatem rozwoju, mimo dość wąskiej, niemal wyłącznie prośrodowiskowej, interpretacji tej koncepcji rozwoju [Borys, Czaja, 2009, s. 51 -75].

5. Druga połowa lat dziewięćdziesiątych wniosła trzy, istotne wartości dodane do badań nad operacjonalizacją wskaźnikową nowego paradygmatu rozwoju. Po pierwsze, zaobserwowano w tym okresie rosnącą świadomość potrzeby odejścia od wąskiej interpretacji paradygmatu na rzecz szerokiego podejścia, integrującego w zrównoważony sposób rozwój gospodarczy, społeczny i ochronę środowiska oraz jego zasobów. Dostrzeżono również, że użycie do opisu istoty tego paradygmatu: cech, ładów, zasad i celów, wzbogaca i konkretyzuje ten opis. Pozwala także coraz lepiej identyfikować subtelności różnic i podobieństw między, tak bardzo powiązanymi ze soba, kategoriami, takimi jak: rozwój zrównoważony, rozwój trwały, rozwój samopodtrzymujący i ekorozwój (preferujący ważność kapitału naturalnego i jego ochrony). Zauważono jednocześnie wzrost

${ }_{4}$ Idea ta została szeroko zaprezentowana w pracy D. Pearce'a i R. Turnera pt.: Economics of the National Resources and the Environment [Pearce, Turner, 1990]. 
znaczenia identyfikacji zasad rozwoju jako głównego nośnika informacji o przyjętym systemie aksjologicznym i zasadniczego generatora sensu ładu zintegrowanego jako układu docelowego rozwoju.

Po drugie, druga połowa lat dziewięćdziesiatych to poczatek procesu implementacji nowego paradygmatu rozwoju. W 1998 roku powstała już baza danych UNCSD, zawierająca doświadczenia i raporty z „fazy testowania” oraz strukturę i listę wstępną wskaźników, które stanowiły punkt wyjścia konstrukcji narodowych list wskaźników, dostosowanych do specyficznych warunków danego kraju oraz celów i założeń narodowych strategii rozwoju. Lista tych wskaźników zawierała opis i charakterystykę każdego z proponowanych wskaźników, jak również praktyczne wskazówki związane z posługiwaniem się nimi i obliczeniami. Wskaźniki zostały podzielone według czterech sfer: społecznej, ekonomicznej, środowiskowej i instytucjonalnej. Rozpoczęto systemowe wprowadzanie nowej koncepcji rozwoju do planowania strategicznego na różnych poziomach zarządzania.

Po trzecie, w tym czasie pojawily się pierwsze polskie prace na temat wskaźników, nazywanych wówczas wskaźnikami „trwałego rozwoju”, to publikacje J. Śleszyńskiego [Śleszyński, 1997; Śleszyński, 1998] lub wskaźnikami „ekorozwoju" - pierwsze publikacje B. Fiedora [Fiedor, 1996] czy autora tego artykułu [Borys, 1998]. W 1996 roku z inicjatywy Ministerstwa Środowiska stworzono koncepcję koordynacji polskich badań i powołano przy Ministerstwie ogólnopolski zespół badaczy z ośrodków naukowych, takich jak: Warszawa, Wrocław i Jelenia Góra. Efekty tego etapu polskich badań zostały zaprezentowane w książce pt.: Wskaźniki ekorożoju [Wskaaźniki..., 1999]. Głównym celem tych badań było przede wszystkim rozpoznanie doświadczeń w budowie zestawów wskaźników, głównie na poziomie międzynarodowym i narodowym. Niezwykle ważnym impulsem do dalszego rozwoju podstaw naukowych i aplikacyjnych wskaźników nowego paradygmatu rozwoju były także badania nad szacowaniem wskarninika catkowitych nakładón materialnych (Total Material Requirements - TMR), prowadzone wspólnie przez Uniwersytet Warszawski z Instytutem na rzecz Ekorozwoju.

6. Pierwsza dekada XXI wieku to czas niezwykle owocny dla rozwoju metodologii pomiaru nowego paradygmatu rozwoju, w którym wystapiły, opisane poniżej, charakterystyczne zjawiska.

Po pierwsze, nowe inspiracje globalne, wynikające z przyjęcia Milenijnych Celów Rozwoju (2000) i przygotowań oraz pokłosia II Szczytu Ziemi w Johannesburgu (2002), a także niemal powszechne uwzględnianie nowego paradygmatu rozwoju w strategiach Unii Europejskiej (Strategia Zrównoważonego Rozwoju Unii Europejskiej, odnowiona w 2006 roku) i w strategiach krajów członkowskich.

Po drugie, $\mathrm{w}$ tym czasie nastąpiło ciekawe, $\mathrm{z}$ socjologicznego punktu widzenia, swoiste "przelanie" się nowego paradygmatu, występującego w tym czasie głównie pod nazwami „rozwoju zrównoważonego” lub/i „rozwoju trwałego”, poza, dotąd dość, hermetyczne środowisko badaczy zajmujących się tą katego- 
ria. Nowy paradygmat stał się przedmiotem badań nowych środowisk naukowych, które dotąd ignorowały tę koncepcję rozwoju. Środowiska te (część środowiska ekonomistów i filozofów) zaczęły traktować tę koncepcję jako obca, wyłącznie polityczną i nienaukowa, jako ideę narzuconą środowisku naukowemu głównie przez polityków. Wystapił więc tu typowy syndrom jej odrzucenia lub zgłaszania „fundamentalnych” wattpliwości. Najbardziej znamienny przykład krytyki nowego paradygmatu to artykuł Szumskiego pt.: Refleksja na temat zrównoważonego rozwoju - çy rozwój zrównoważony jest fikecja utopia, iluzja ç̧ oszustwem? [Szumski, 2008].

Po trzecie, zjawisku temu towarzyszyły również zjawiska pozytywne, wzmacniania fundamentów teoretycznych ekonomii ekologicznej i ekonomii rozwoju zrównoważonego [np.: Rogall 2010, s. 11-43; Ekonomia..., 2011], a także wdrażania nowych, ważnych metodologicznych aspektów do analiz wskaźnikowych. Jako przykład można tu przytoczyć zauważony, zwłaszcza przez OECD, istotny dla tych analiz problem rozszczepienia (decoupling) warunków środowiskowych od wzrostu ekonomicznego. Stało się to jednym z głównych celów Strategii Środowiskowej dla Pierwszej Dekady XXI wieku, przyjętej w 2001 roku przez Ministrów Środowiska krajów OECD. Termin decoupling odnosi się do przełamywania połączeń pomiędzy złym środowiskiem (environmental bads) a dobrami ekonomicznymi (economic goods). Do koncepcji decoupling indicators nawiązywały od pierwszych lat obecnego wieku także badania wskaźnikowe Europejskiej Agencji Środowiska (EEA).

Po czwarte, pierwsze lata obecnego wieku w Polsce przyniosły konkretne propozycje zestawów wskaźników nowego paradygmatu rozwoju na trzech poziomach zarządzania: lokalnym (2001 rok), regionalnym (2002 rok) i krajowym (lata 2003-2004). Badania te, ściśle powiązane ze zmianami w administrowaniu danymi statystycznymi w Głównym Urzędzie Statystycznym m.in. w ramach restrukturyzacji Banku Danych Lokalnych (BDL), zmierzały przede wszystkim do opracowania zasad wdrożenia zestawu wskaźników do praktyki pomiaru zrównoważonego rozwoju oraz weryfikacji przydatności proponowanych zestawów wskaźników w procesach przygotowywania i realizacji polityki zrównoważonego rozwoju (strategii i programów). Jednak w tym okresie dominującą rolę koordynującą odgrywało Ministerstwo Środowiska, a statystyka publiczna i jej agendy (urzędy statystyczne) odgrywały rolę mniej lub bardziej życzliwego obserwatora i dawcy danych.

Po piąte, rozpoczął się w tym czasie bardzo ważny etap rozwoju metodologii pomiaru nowego paradygmatu rozwoju, który można nazwać umownie etapem implementacyjnym. Był on realizowany od roku 2004, choć na poziomie lokalnym proces implementacji wyników badań wskaźnikowych rozpoczął się znacznie wcześniej. Wśród najważniejszych zadań tego etapu należy wymienić przede wszystkim: wprowadzenie zestawów wskaźników do systemów monitorowania realizacji polityk (strategii, programów), upowszechnienie opracowanych modułów wskaźników w audytach lokalnych, restrukturyzację Banku Danych Lokalnych przez wzbogacenie zasobów danych w celu szacowania 
wartości wskaźników, jak również wprowadzenie jasnych reguł udostępniania modułu wskaźnikowego BDL.

Mniej więcej od połowy minionej dekady obecnego wieku widać stopniowy proces przejmowania inicjatywy przez statystykę publiczną oraz resorty pozaśrodowiskowe, np. Ministerstwo Infrastruktury (wskaźniki zrównoważonego transportu) czy Ministerstwo Gospodarki (wskaźniki zrównoważonej produkcji i konsumpcji).

Od 2009 roku realizowano ważne projekty budowy wskaźników szczególnie w dwóch wojewódzkich urzędach statystycznych: we Wrocławiu - moduł regionalny (wojewódzki), przekształcony w program statystyczny GUS „STRATEG” (m.in. menu wskaźnikowe dla wojewódzkich strategii rozwoju) i w Katowicach - moduł krajowy. Ważnym uzupełnieniem tych prac jest inicjatywa Związku Miast Polskich w Poznaniu, polegająca na stworzeniu w ramach Systemu Analiz Samorządowych (SAS) - modułu lokalnych wskaźników zrównoważonego rozwoju.

\section{Stan metodologii pomiaru nowego paradygmatu rozwoju - trzy wybrane problemy}

\subsection{Czy wiemy co chcemy mierzyć? - problem pierwszy}

Można od kilku lat zaobserwować, mimo trwających nadal dyskusji, względną stabilizację w rozpoznaniu istoty nowego paradygmatu rozwoju. Jeśli jednak tak nie jest, czyli nie ma tej stabilizacji i „rację” maja ci badacze, którzy twierdzą, że nowy paradygmat rozwoju jest mętną idea, to, czy oznacza to, że najpoważniejsze agendy organizacji międzynarodowych oraz międzynarodowe zespoły badawcze buduja zestawy wskaźników na różnych poziomach dla „niewiadomo jakiej” koncepcji rozwoju. Wydaje się to bardzo mało prawdopodobne. Zatem, czy nowy paradygmat rozwoju jest dostatecznie skonkretyzowany (zoperacjonalizowany)? Jaka argumentacją dysponujemy?

Nowy paradygmat rozwoju jest urzeczywistniany w ostatnich latach pod nazwami zrównoważonego, trwałego, samopodtrzymującego się rozwoju czy ekorozwoju. Paradygmat ten przestał być już tylko ogólną - często niezrozumiałą, mętną idea, której istotą jest zasada sprawiedliwości międzypokoleniowej w dostępie do różnych środowisk: przyrodniczego, kulturowego, ekonomicznego itp. Współcześnie koncepcja ta jest kategorią w dużym stopniu operacyjną - o rosnącej konkretności na różnych poziomach zarządzania. Fundamenty pomiaru tworzy konkretyzacja nowego paradygmatu rozwoju, która odbywa się przez identyfikację:

- $\quad$ cech rozwoju: trwałości, zrównoważoności i samopodtrzymywania;

- zasad rozwoju stanowiących „filtr” podstawowy dla selekcji wskaźników;

- celów (jako pozytywnych stanów docelowych rozwoju) i ładów (społecznego, ekonomicznego i środowiskowego, w tym przestrzennego).

Należy zauważyć, że dla metodologii jest to fundamentalne stwierdzenie, bowiem oznacza ono, że pomiar wskaźnikowy urzeczywistniania nowego paradygmatu rozwoju 
można oprzeć na mierzeniu stopnia realizacji jego konstytutywnych parametrów, czyli stopnia spełnienia wzorców (stanów najbardziej pożądanych z punktu widzenia określonego systemu wartości - co najmniej umiarkowanego antropocentryzmu): cech, zasad i benchmarków strategicznych - celów i ładów. Podejście to nie zawsze jest uznawane za podstawę przyszłego rozwoju operacjonalizacji wskaźnikowej nowego paradygmatu rozwoju. Wydaje się, że są tu co najmniej trzy „historyczne” źródła takiej sytuacji.

Po pierwsze, istnieja pozorne kłopoty z tłumaczeniem Sustainable Development, bowiem nie może ten angielski termin być raz tłumaczony jako rozwój trwały, raz jako rozwój zrównoważony czy jako rozwój sustensywny (samopodtrzymujący) bądź ekorozwój, skoro terminy te mają swoje angielskie odpowiedniki: Durable Development, Balanced Development, Sustainable Development i Ecodevelopment.

Po drugie, w obiegu potocznym i nierzadko w obiegu naukowym funkcjonują od wielu lat wąskie i szerokie interpretacje nowego paradygmatu rozwoju. Wykreowało to kategorię ekorozwoju jako przykład wąskiej interpretacji tego paradygmatu. W ostatnich latach jest to coraz rzadsza interpretacja i częściej dominuje takie ujęcie tego paradygmatu, którego benchmarkiem jest ład zintegrowany.

RYSUNEK 1.

\section{Koncepcje tworzące i wzbogacające nowy paradygmat rozwoju - rozwój zintegrowany}

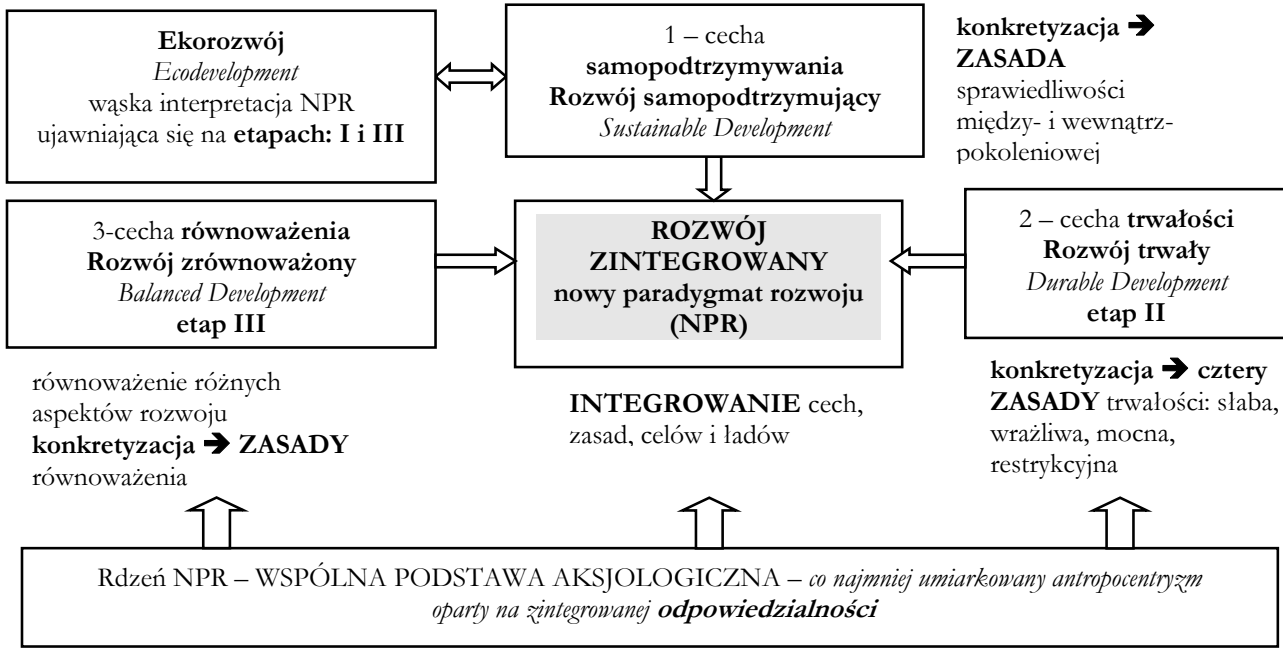

Objaśnienie zasad trwałości i pojęcia umiarkowanego antropocentryzmu jest przedstawione m.in. w przywoływanej pracy: [Wską́niki..., 2005].

Źródło: opracowanie własne.

Po trzecie, nieustające dyskusje na temat cech nowego paradygmatu rozwoju ujawniły dwa wykluczające się podejścia - podejście konkurencyjne i podejście komple- 
mentarne. Mianowicie, cecha równoważenie (i kategoria rozwój zrównoważony) konkuruje $\mathrm{z}$ trwałościa ( $\mathrm{z}$ rozwojem trwałym) o obecność w nazwie tego paradygmatu z tym, że „źródłowa” cecha samopodtrzymywanie (rozwój sustensywny/samopodtrzymujący) dawno już straciła na popularności. Należy tu podkreślić, że cecha samopodtrzymywania rozwoju ma fundamentalne znaczenie, bowiem wyznacza początek tworzenia się zrębów teoretycznych i implementacyjnych nowego paradygmatu rozwoju.

W tej pracy proponuje się podejście wykorzystujące w sposób komplementarny (nie substytucyjny) wymienione cechy rozwojowe jako równoprawne w opisie nowego paradygmatu rozwoju, które w tym kontekście proponuje się nazwać rozwojem zintegrowanym. Wprowadzona kategoria sugeruje w sposób oczywisty nie tylko integrowanie cech rozwojowych, ale także wszystkich pozostałych, wymienionych wcześniej, parametrów konstytuujących ten nowy paradygmat rozwoju, tzn. integrowanie zasad rozwoju (trwałości, równoważenia i sustensywności) oraz integrowanie ładów (w ład zintegrowany).

Uproszczoną identyfikację kolejnych etapów konkretyzacji istoty rozwoju zintegrowanego przedstawia rysunek 1 .

\subsection{Czy istnieją w Polsce systemy pomiaru nowego paradygmatu rozwoju na po- szczególnych poziomach zarządzania? - problem drugi}

\section{Poziom lokalny}

Na poziomie lokalnym szczególne znaczenie mają w Polsce trzy inicjatywy:

- realizowany także w Polsce europejski program Urban Audit;

- „prowskaźnikowa” ewolucja Banku Danych Lokalnych;

- rozszerzenie „statystycznej” inicjatywy sektora samorządowego, funkcjonującej pod nazwą System Analiz Samorządowych (SAS), o moduł wskaźników nowego paradygmatu rozwoju.

Program Urban Audit to, podjęte w maju 1998 roku, wspólne przedsięwzięcie Komisji Europejskiej, Dyrekcji Generalnej do spraw Polityki Regionalnej Unii Europejskiej oraz Eurostatu, który jest koordynatorem wszystkich prac, a wykonawcami sa: krajowe urzędy statystyczne, urzędy miast i samorządy terytorialne. Ocena implementacji nowego paradygmatu rozwoju jest dokonywana na poziomie lokalnym i oparta na obiektywnych i porównywalnych danych, dotyczących 258 największych miast z krajów Unii Europejskiej. Badanie przeprowadzono na ponad 336 zmiennych, na podstawie których obliczono ponad 280 wskaźników stanowiących narzędzie do dokonywania dalszych analiz. Ta analiza wskaźnikowa, co z metodologicznego punktu widzenia jest godne podkreślenia, łączy się z badaniem subiektywnej jakości życia w miastach (odpowiedzi na 23 pytania w wywiadzie telefonicznym). W Programie uczestniczą 23 polskie miasta (w tym wszystkie wojewódzkie), a koordynacja w ramach statystyki publicznej zajmuje się Centrum Statystyki Miast Urzędu Statystycznego w Poznaniu [Dokument elektro- 
niczny, tryb dostępu: http://www.stat.gov.pl/cps/rde/xbcr/gus/PUBLurban_audit.pdf, data wejścia: 10.01 .2014$]^{5}$.

Bank Danych Lokalnych (BDL) - to obecnie największy w Polsce, funkcjonujący od 1995 roku, uporządkowany i udostępniany w Internecie zbiór informacji o sytuacji: społecznej, gospodarczej, demograficznej oraz stanie środowiska, opisujący wszystkie poziomy jednostek samorządu terytorialnego: regionalny - województwa i lokalny - powiaty oraz gminy, a także regiony i podregiony stanowiące elementy nomenklatury jednostek terytorialnych dla celów statystycznych. Mniej więcej do połowy pierwszej dekady obecnego wieku, BDL funkcjonował w swej dominującej części jako „bezwskaźnikowa” baza danych. Z tego powodu między innymi, realizowany w latach 2001-2004, projekt Ministerstwa Środowiska budowy lokalnych, regionalnych i krajowych modułów wskaźników „zrównoważonego rozwoju” w ramach BDL nie trafil na podatny grunt $\mathrm{w}$ agendach statystyki publicznej.

Zachodzące w ostatnich latach zmiany w BDL to ważny przejaw doskonalenia, publicznie dostępnych, baz danych w kierunku tworzenia systemu modułów wskaźników opisujących w wymierny sposób urzeczywistnianie nowego paradygmatu rozwoju [Dokument elektroniczny, tryb dostępu: http://www.stat.gov.pl/wroc/27_PLK_ HTML.htm, data wejścia: 20.11.2013]. Zmiany te głównie polegają na:

- udostępnianiu wybranych cech także dla poziomu miejscowości statystycznych;

- poszerzaniu zakresu danych krótkookresowych;

- znaczacym poprawianiu funkcjonalności interfejsu;

- potraktowaniu zasobów BDL jako ważnego źródła wiedzy o stopniu wdrażania nowego paradygmatu rozwoju na poziomie lokalnym i regionalnym, czyli potraktowaniu zasobów danych statystyki publicznej, a zwłaszcza statystyki lokalnej i statystyki regionalnej jako naturalnej podstawy budowy wskaźników niezbędnych do organizowania systemów monitoringu realizacji różnego typu dokumentów strategicznych.

W Polsce funkcjonują już na poziomie lokalnym dwa systemy analizy wská́nikowej, które łączą pomiar nowego paradygmatu rozwoju z monitoringiem celu nadrzędnego tego rozwoju - jakości życia. Pierwszy system to, wspomniany już wcześniej, europejski program Urban Audit, drugi zaś - to oryginalny, polski pomysł monitoringu wskaźnikowego, realizowany w ramach Systemu Analiz Samorządowych przez Związek Miast Polskich. W fazie trzeciej rozwoju SAS (tj. od roku 2007) obok celu dotychczas realizowanego (badania jakości usług publicznych) pojawił się nowy cel, istotnie rozszerzający zakres tego systemu - wzmocnienie systemów monitoringu wskaźnikowego lokalnych

\footnotetext{
${ }^{5}$ Rozpowszechnianie informacji o programie Urban Audit jest prowadzone przez stronę internetowa Komisji Europejskiej [Dokument elektroniczny, tryb dostępu: http://www.urbanaudit.org, data wejścia: 21.11.2013], która umożliwia m.in. uzyskanie informacji o profilu miasta, pokazuje ranking miast pod względem badanej cechy, pozwala również na porównanie informacji pomiędzy wybranymi miastami. Dane statystyczne w ramach projektu Urban Audit są także dostępne w bazie danych Eurostatu [Dokument elektroniczny, tryb dostępu: http://europa.eu.int/comm/eurostat/, data wejścia: 21.11.2013]. Aktualne informacje o programie oraz wyniki audytu dla 258 miast europejskich zamieszczono na stronie internetowej Komisji Europejskiej, poświęconej polityce regionalnej [Dokument elektroniczny, tryb dostępu: http://ec.europa.eu/regional_policy/ themes/Urban/audit/ index_pl.htm, data wejścia: 21.11.2013].
} 
polityk rozwoju przez budowę dwóch dodatkowych modułów wskaźnikowych: zrównoważonego rozwoju i jakości życia mieszkańców gmin. Moduł wskaźników zrównoważonego rozwoju SAS na tle innych systemów wskaźników wyróżnia się możliwościa obliczania syntetycznych miar zrównoważonego rozwoju dla dziedzin i ładów (uwzględnia się: ład społeczny, ład środowiskowo-przestrzenny i ład gospodarczy). W ramach systemu jest oferowana samorządom ankieta badania jakości życia wraz z metodyka przeprowadzenia badania oraz strukturą raportu. Moduł tego systemu liczy łącznie ponad 250 wskaźników z równomiernym podziałem zbioru wskaźników na trzy łady: społeczny, gospodarczy i środowiskowo-przestrzenny. Jego zasilanie jest oparte na zasobach Banku Danych Lokalnych GUS [Raport..., 2008; Dokument elektroniczny, tryb dostępu: http://www.sas.zmp. poznan.pl, data wejścia: 5.01.2014].

\section{Poziom regionalny (wojewódzki)}

Jeszcze kilka lat temu pomiar nowego paradygmatu rozwoju na tym poziomie zarządzania był z pewnością najsłabszym ogniwem monitoringu postępu w implementacji tego paradygmatu. W ostatnich latach w Urzędzie Statystycznym we Wrocławiu został skonstruowany w ramach BDL uniwersalny moduł umożliwiający monitorowanie nowego paradygmatu rozwoju na poziomie niższym niż kraj. Punktem odniesienia do stworzenia tego modułu były wskaźniki opracowane przez Eurostat. Moduł ten ma stanowić pewnego rodzaju „rdzeń” umożliwiający ocenę i porównywanie poszczególnych jednostek samorządu terytorialnego. Pierwszą praktyczną weryfikacją tej inicjatywy były taksonometryczne badania porównawcze polskich województw z wykorzystaniem także miar syntetycznych [Analiza ..., 2011].

Rozwinięciem tej inicjatywy jest program statystyczny GUS „STRATEG” [Dokument elektroniczny, tryb dostępu: strateg. stat.gov.pl, data wejścia: 10.01.2014], którego zadaniem jest integracja systemu monitoringu strategii rozwoju. Zebrano w nim około 950 wskaźników, a także analizy statystyczne, opracowania i raporty. Dokonano w nim również integracji danych statystycznych $z$ danymi administracyjnymi, pochodzącymi $z$ administracji publicznej różnych poziomów (od poziomu krajowego po poziom lokalny). System ten, opracowany w Głównym Urzędzie Statystycznym na zlecenie Ministerstwa Rozwoju Regionalnego, działa od października 2013 jako publicznie dostępna baza wskaźników kluczowych dotycząca monitorowania polityk rozwoju. Zasadnicze funkcje systemu obejmuja: prezentację stanu realizacji strategii, grupowanie danych według jednostek samorządu terytorialnego, analizy porównawcze wskaźników na poziomie międzynarodowym w ramach Unii Europejskiej. Oprócz prezentacji danych liczbowych, system ten stanowi jednocześnie ważne źródło informacji metodologicznych. System STRATEG będzie rozwijany przez Główny Urząd Statystyczny przynajmniej do 2022 roku równocześnie jako menu wskaźnikowe dla wojewódzkich strategii rozwoju.

\section{Poziom krajowy}

W praktyce planowania strategicznego wyodrębnia się w zależności od poziomu zarządzania, wymienione już, trzy łady (społeczny, gospodarczy i środowiskowy) bądź 
cztery przez wyodrębnienie ładu instytucjonalno-politycznego z ładu społecznego (pierwsza czwórka) lub ładu przestrzennego z ładu środowiskowego (druga czwórka) bądź pięć, gdy stosuje się najbardziej rozwiniętą formę ładu zintegrowanego. Integralność ładów realizuje się dzięki zrównoważonej ochronie kapitałów: przyrodniczego (środowiska), społecznego i ludzkiego oraz antropogenicznego (wytworzonego przez człowieka, a zwłaszcza kapitału kulturowego i ekonomicznego).

Takie podejście - przy udziale autora tego opracowania - posłużyło tworzeniu krajowego systemu wskaźników zrównoważonego rozwoju w ramach projektu badawczego przeprowadzonego przy wsparciu Komisji Europejskiej w Urzędzie Statystycznym w Katowicach, w latach 2010-2011 [W sparcie..., 2011]. Wyniki tych prac przedstawia tabela 1., ilustrująca strukturę ilościową krajowych wskaźników nowego paradygmatu rozwoju według ładów i obszarów tematycznych ${ }^{6}$.

TABELA 1.

Krajowe wskaźniki zrównoważonego rozwoju według ładów i obszarów tematycznych

\begin{tabular}{|c|c|c|}
\hline \multicolumn{3}{|c|}{ Zrównoważony rozwój kraju } \\
\hline Lady & Obszary tematyczne & $\begin{array}{c}\text { Liczba } \\
\text { wskaźników }\end{array}$ \\
\hline 1. Społeczny & $\begin{array}{l}\text { 1.1. Zmiany demograficzne } \\
\text { 1.2. Zdrowie publiczne } \\
\text { 1.3. Integracja społeczna } \\
\text { 1.4. Edukacja } \\
\text { 1.5. Dostep do rynku pracy } \\
\text { 1.6. Bezpieczeństwo publiczne } \\
\text { 1.7. Wzorce konsumpcji }\end{array}$ & $\begin{array}{l}4 \\
5 \\
4 \\
4 \\
5 \\
1 \\
3\end{array}$ \\
\hline \multicolumn{2}{|r|}{21 Rozwói onsnodarczy } & 26 \\
\hline 2. Gospodarczy & $\begin{array}{l}\text { 2.1. Rozwój gospodarczy } \\
\text { 2.2. Zatrudnienie } \\
\text { 2.3. Innowacyjność } \\
\text { 2.4.Transport - infrastruktura } \\
\text { 2.5. Wzorce produkcji }\end{array}$ & $\begin{array}{l}8 \\
3 \\
4 \\
1 \\
3\end{array}$ \\
\hline \multirow[b]{2}{*}{ 3. Środowiskowy } & Razem & 19 \\
\hline & $\begin{array}{l}\text { 3.1. Zmiany klimatu } \\
\text { 3.2. Energia } \\
\text { 3.3. Ochrona powietrza } \\
\text { 3.4. Ekosystemy morskie } \\
\text { 3.5. Zasoby słodkiej wody } \\
\text { 3.6. Użytkowanie gruntów } \\
\text { 3.7. Bioróżnorodność } \\
\text { 3.8. Gospodarka odpadami }\end{array}$ & $\begin{array}{l}3 \\
4 \\
4 \\
1 \\
4 \\
3 \\
4 \\
3 \\
\end{array}$ \\
\hline \multicolumn{2}{|r|}{ Razem } & 26 \\
\hline 4. Instytycjonalno-polityczny & $\begin{array}{l}\text { 4.1. Globalne partnerstwo } \\
\text { 4.2. Polityka spójności i efektywności } \\
\text { 4.3. Otwartość i uczestnictwo } \\
\text { 4.4. Aktywność obywatelska }\end{array}$ & $\begin{array}{l}1 \\
2 \\
3 \\
1\end{array}$ \\
\hline & $\begin{array}{r}\text { Razem } \\
\text { OGÓEEM }\end{array}$ & $\begin{array}{c}7 \\
78\end{array}$ \\
\hline
\end{tabular}

Źródło: opracowanie własne na podstawie danych Urzędu Statystycznego w Katowicach.

${ }^{6}$ Wskaźniki dla monitorowania polityki ekologicznej państwa zawiera m.in.: [Opracowanie..., 2004]. 


\subsection{Jaki jest stan metodologii pomiaru nowego paradygmatu rozwoju w poszczególnych sektorach i dyscyplinach naukowych? - problem trzeci}

Kluczowym problemem związanym z rozpoznaniem nowego paradygmatu rozwoju jest jego konkretyzacja sektorowa (dziedzinowa). Jest już dobrze znana istota sektorowa tego paradygmatu, przede wszystkim w odniesieniu do:

- „zrównoważonego” transportu [OECD..., 2002];

- „zrównoważonej” produkcji i „zrównoważonej” konsumpcji [np. Analiza..., 2008];

- „Zrównoważonej” turystyki [np. Nitkiewicz-Jankowska, 2014];

- „zrównoważonego” rolnictwa [Kociszewski, 2013];

- „zrównoważonej” gospodarki leśnej czy „zrównoważonej” gospodarki energetycznej.

Rośnie także dorobek naukowy, identyfikujący cechy nowego paradygmatu w takich dyscyplinach i subdyscyplinach naukowych, jak ekonomia (ekonomia „zrównoważonego” rozwoju), [np. Rogall, 2010; Ekonomia..., 2011], logistyka („zrównoważona” logistyka), [Skowrońska, 2009] czy finanse (,zrównoważone” finanse), [Finance..., 2013]. Jednak nie we wszystkich wymienionych sektorach jest jednakowe zainteresowanie i zaawansowanie procesów tworzenia monitoringu wskaźnikowego. Dobre praktyki w konstruowaniu takich zestawów wskaźników można zaobserwować głównie w sektorach transportu oraz zrównoważonej konsumpcji i produkcji.

Problem pomiaru wskaźnikowego cech zrównoważenia transportu jest niezwykle trudny, ponieważ w literaturze i w licznych dokumentach strategicznych organizacji międzynarodowych i krajowych obserwuje się bardzo zróżnicowane podejście do tego zagadnienia [Litman, 2008]. Istnieją pewne trudności zwłaszcza z rozróżnieniem w praktyce planowania strategicznego dwóch kluczowych pojęć: zrónnoważonego rozwoju transportu (Sustainable Development of Transportation) i zrónnoważonego transportu (Sustainable Transportation). Pojęcie drugie częściej występuje w krajowych i międzynarodowych dokumentach strategicznych rozwoju transportu i w różnego typu deklaracjach. Szczególną aktywność w określaniu istoty tych pojęć przejawia OECD, Unia Europejska oraz Centrum Zrównoważonego Rozwoju Transportu w Toronto.

Mimo to, w tej różnorodności można wyselekcjonować wskaźniki powtarzające się przy każdym podejściu do pomiaru postępów wprowadzania tej koncepcji rozwoju transportu w życie z uwzględnieniem dwóch cech nowego paradygmatu rozwoju: równoważenia i samopodtrzymywania. Cechy te ujawniają się w następujących kryteriach:

- dostępności do usług transportowych zgodnej z wymogiem bezpieczeństwa zdrowotnego i ekologicznego (oddziaływania na ekosystemy) z uwzględnieniem zasady sprawiedliwości międzypokoleniowej;

- efektywności ekonomicznej;

- $\quad$ ograniczania wpływu na środowisko (negatywnych efektów zewnętrznych) i wykorzystania przestrzeni (gruntów) [Raport..., 2009].

Zatem, transport zgodny z tym paradygmatem musi $\mathrm{w}$ zrównoważonym stopniu odzwierciedlać zróżnicowane cele: gospodarcze, społeczne i środowiskowe. Właśnie te kryteria definicyjne zostały przyjęte w 2004 roku przez European Conference of Ministers of 
Transportation OECD i w 2005 roku przez Centre for Sustainable Transportation w Toronto. Są one także preferowane przez wielu ekspertów, włącznie z Transportation Research Board's Sustainable Transportation Indicators Subcommittee, a także European Council of Ministers of Transport.

Na podstawie analizy tych kryteriów oraz celów i priorytetów polityki transportowej Unii Europejskiej i Polski [Polityka..., 2005; WHITE..., 2001] można, jak się wydaje, zidentyfikować kluczowe cechy pomiarowe rozwoju transportu uwzględniającego w zrównoważony sposób trzy sfery: społeczna, ekonomiczną i środowiskowa. Zestawy tych cech prezentuje rysunek 2 . Wymienione tam cechy sa podstawa generowania zestawów wskaźników rozwoju transportu zgodnego z nowym paradygmatem.

Kolejny przykład rozwoju sektorowej metodologii analizy wskaźnikowej nowego paradygmatu rozwoju dotyczy produkcji i konsumpcji. Problem pomiaru wskaźnikowego cech konsumpcji zgodnej z nowym paradygmatem rozwoju jest, podobnie jak w przypadku transportu, niezwykle trudny z tego powodu, że koncepcja „zrównoważonej” lub „trwałej” konsumpcji (w zależności od tego, jakie cechy nowego paradygmatu się eksponuje) nie ma i nie może mieć charakteru autonomicznego. Jest ściśle związana z koncepcją zrównoważonej produkcji oraz koncepcją zrównoważonej logistyki i zrównoważonego marketingu.

RYSUNEK 2.

\section{Równoważenie cech w zrównoważonym rozwoju transportu}

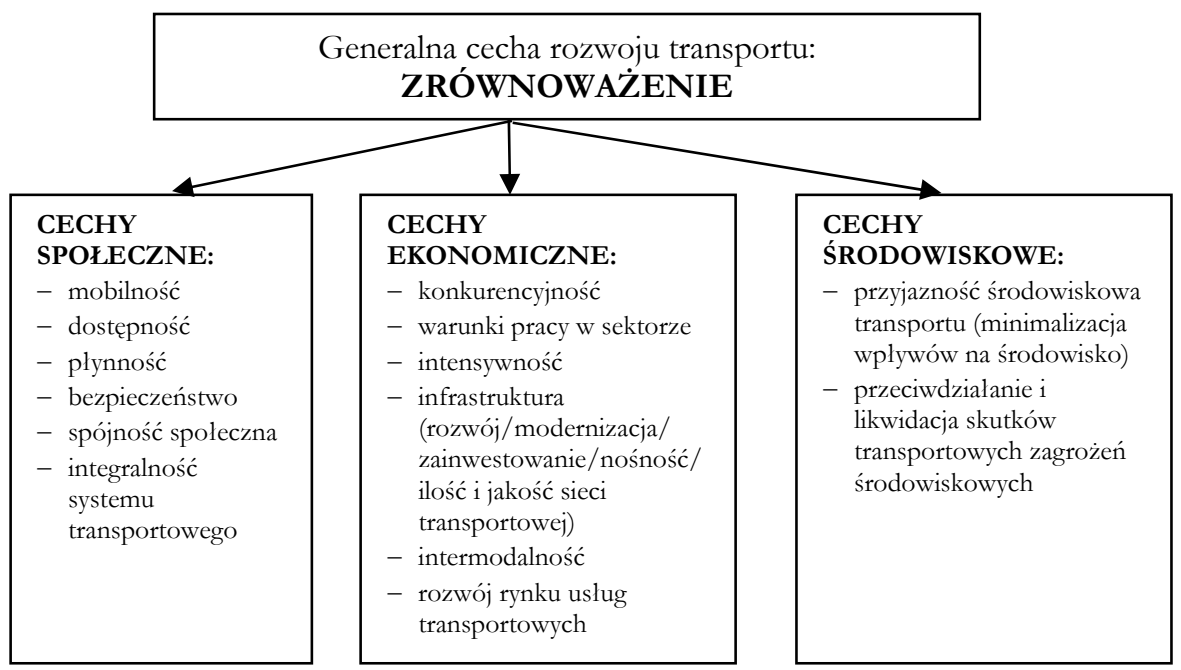

Źródło: opracowanie własne, także [Raport..., 2009].

To te koncepcje tworzą swoisty Trójkat rónnoważenia, który w układzie podmiotowym - w pewnym uproszczeniu - tworzy zrównoważony (odpowiedzialny) produ- 
cent, zrównoważony sprzedawca i zrównoważony konsument. W tym Trójkaccie, co jest oczywiste, szczególną wagę przykłada się do koncepcji zrównoważonej produkcji i zrównoważonej konsumpcji. W większości dokumentów strategicznych pojęcia te zawsze traktuje się łącznie $\mathrm{i} \mathrm{w}$ wielu przypadkach sa trudności $\mathrm{z}$ ich wyraźnym rozróżnieniem [Changing..., 2003]. Jednak nie można wyolbrzymiać problemu dość płynnego (nieostrego) odróżniania obu tych kategorii, ponieważ podstawowa istota tych koncepcji jest w zasadzie ustabilizowana.

Określenie głównych cech pomiarowych zrównoważonej konsumpcji, wynikających $z$ istoty tej koncepcji oraz analizy zasad i celów strategicznych, wymaga refleksji nad tym co koncepcje „zrównoważonej” konsumpcji i „zrównoważonej” produkcji łączy, a co jest dla nich specyficzne. Do tych łącznych uwarunkowań należy przede wszystkim zaliczyć:

- $\quad$ współdziałanie w ramach całego Trójkąta rónnoważenia, a zwłaszcza konsumentów i producentów;

- $\quad$ zintegrowana edukację i świadomość w ramach tego Trójkata, bez tej integracji zmiana „złych nawyków” producenckich i konsumenckich będzie tylko pustym sloganem;

- informowanie o właściwościach produktów, w tym o oddziaływaniu na środowisko przyrodnicze i zdrowie czlowieka; chodzi tu głównie o kompletność i prawdziwość tego procesu informowania (wiarygodność, minimalizacja manipulowania hasłami proekologicznymi czy prozdrowotnymi itp.);

- $\quad$ obserwację całego cyklu życia produktów, w tym koncentrację na poużytkowej fazie tego cyklu.

$\mathrm{Na}$ tle tych ogólnych postulatów można budować względnie autonomiczne zestawy wskaźników zrównoważonej produkcji i zrównoważonej konsumpcji. W przywoływanym opracowaniu [Analiza..., 2008] zaproponowano zestaw 88 wskaźników „zrównoważonej" produkcji z uwzględnieniem następujących dziedzin i cech pomiarowych:

- gospodarka recyrkulacyjna: 44 wskaźniki (w tym emisyjność gospodarki 6 wskaźników; energochłonność gospodarki - 12 wskaźników; materiałochłonność i odpadowość gospodarki - 16 wskaźników; integralność i wydajność ekosystemów - 8 wskaźników);

- zintegrowana polityka produktowa: 19 wskaźników;

- działania na rzecz ekoinnowacji: 9 wskaźników;

- działania na rzecz zrównoważonego transportu: 16 wskaźników.

Przy konstrukcji propozycji, liczącego 19 wskaźników, modułu zrównoważonej konsumpcji przyjęto następujące główne cechy pomiarowe, którym zostały przypisane odpowiednie wskaźniki:

- edukacja konsumentów: 8 wskaźników;

- dostępność informacji o produktach: 1 wskaźnik;

- samoorganizacja konsumentów: 3 wskaźniki;

- dostęp konsumentów do produktów o wysokiej jakości: 6 wskaźników; -

- prozdrowotne i prośrodowiskowe zachowania konsumentów: 1 wskaźnik [Analiza..., 2008]. 
W Polsce, w stworzonych modułach wskaźnikowych widać zatem dość dużą dysproporcję między zbiorem wskaźników „zrównoważonej” konsumpcji (19) a zbiorem wskaźników „zrównoważonej” produkcji (88). Niestety, szacowanie wartości większości wskaźników „zrównoważonej” konsumpcji opiera się na danych pozastatystycznych. Statystyka publiczna wyraźnie nie nadąża za potrzebami pomiaru zrównoważonej konsumpcji. Tę niekorzystną sytuację, przynajmniej częściowo, zmieniają osiagnięte w 2011 roku wyniki w projekcie koordynowanym przez Urząd Statystyczny w Katowicach. W jego ramach opracowano nowy moduł pomiaru wskaźnikowego „zrównoważonej” konsumpcji [Dokument elektroniczny, tryb dostępu: http://www.stat.gov.pl/katow/ index_PLK_HTML.htm, data wejścia: 12.01.2014]. Jednak realizacja tego projektu wymaga kompleksowej analizy i oceny dostępności danych (możliwości ich pozyskiwania) oraz przeprowadzenia takich zmian w obecnym systemie statystyki, które umożliwiłyby efektywne i systematyczne wzbogacanie zestawu wskaźników „zrównoważonej” konsumpcji w dane.

\section{Podsumowanie}

1. Nowy paradygmat rozwoju ma już istotnie zaawansowaną metodologię analizy wskaźnikowej na różnych poziomach zarządzania - na poziomach: międzynarodowym, krajowym, regionalnym i lokalnym, choć nadal istnieje wiele obszarów „do zagospodarowania” wskaźnikowego. Dotyczy to zwłaszcza wskaźników ładu przestrzennego i ładu instytucjonalnego.

2. Nastapiło ważne, swoiste ,uzdrowienie instytucjonalne” związane z rozwojem metodologii pomiaru nowego paradygmatu rozwoju. W Polsce, w latach dziewięćdziesiątych i w pierwszych latach nowego wieku dominującą rolę koordynująca odgrywało Ministerstwo Środowiska, a statystyka publiczna i jej agendy (urzędy statystyczne) odgrywały rolę, mniej lub bardziej, życzliwego obserwatora i dawcy danych. W przybliżeniu, od połowy minionej dekady obecnego wielu widać stopniowy proces przejmowania inicjatywy przez statystykę publiczną oraz resorty pozaśrodowiskowe, np. Ministerstwo Infrastruktury (wskaźniki zrównoważonego transportu) czy Ministerstwo Gospodarki (wskaźniki zrównoważonej produkcji i konsumpcji).

3. Wyraźnie występuje zmiana pokoleniowa badaczy zajmujących się analizą wskaźnikową i duża dynamika rozwoju - na podstawie ogólnej metodologii wskaźnikowej - sektorowych zestawów wskaźników: zielonej gospodarki (Green Economy), zrównoważonej produkcji i konsumpcji, zrównoważonej turystyki, zrównoważonego transportu itp. Dynamicznie wzrosła również liczba wniosków badawczych związanych tematycznie z nowym paradygmatem rozwoju, składanych w ostatnich latach w Narodowym Centrum Nauki.

4. Ocena stanu metodologii pomiaru nowego paradygmatu rozwoju ukazuje jeszcze wiele otwartych problemów, które są, niewatpliwie, ważnymi wyzwaniami do dalszych badań. Szczególnie ważne będzie sformułowanie stosunkowo jasnych odpowiedzi na następujące pytania: 
- $\quad$ jak łączyć pomiar wskaźnikowy jakości życia z pomiarem nowego paradygmatu rozwoju?

- $\quad$ jak wykorzystać ogromny potencjał tkwiący we wskaźnikowych analizach przyczynowo-skutkowych?; tworzenie podstaw informacyjnych do analizy wskaźnikowej w układzie przyczynowo-skutkowym to jedno z najważniejszych wyzwań statystyki i badań nad pomiarem postępów w realizacji nowego paradygmatu rozwoju. Ostatnie lata nie przyniosły na tym polu wyraźnego postępu, mimo ogromnego znaczenia tego podejścia dla monitoringu strategii rozwoju, zwłaszcza na poziomie lokalnym;

- czy można utrzymywać w zestawach wskaźniki „obce” (tzw. konie trojańskie) niewyrażające sedna nowego paradygmatu rozwoju? Jak sprawnie - przy maksymalnej ochronie szeregów czasowych - przeprowadzić proces wymiany wskaźników „obcych”? Dotyczy to zwłaszcza wskaźnika PKB per capita czy wskaźników jakości usług zdrowotnych;

- $\quad$ jak usprawnić proces decyzyjny wyboru funkcji preferencji (ocen) przy jawnym uwzględnieniu aksjologii w trakcie tych wyborów? Jak długo w prowadzonych pomiarach można udawać, że istnieją tylko stymulanty i destymulanty, a nie istnieją nominanty?

\section{Literatura}

Analiza wskaźnikowa zrównoważonego rozwoju wojewódžtw w latach 2005 - 2009 2011, US. Wrocław, dokument elektroniczny, tryb dostępu: [http://www.stat.gov.pl/wroc/ 27_PLK_HTML.htm, data wejścia: 22.11.2013].

Analiza wską̧ników zrównoważonej produkcji i konsumpcji w ramach prazygotowania oraz realizacji Programu na ræecz. zrównoważonych wzorców produkcji i konsumpcji 2008, T. Borys (red.), Jelenia Góra - Warszawa, dokument elektroniczny, tryb dostępu: [http://www.mg.gov.pl/raporty, data wejścia: 22.11.2013].

Borys T. 1998 Teoretyczne podstawy konstruowania wskaźników ekoroz̨uju, „Sterowanie Ekorozwojem", Białystok.

Borys T., Czaja S. 2009 Badania nad zrównowažonym rozwojem w polskich ośrodkach naukonych, [w:] D. Kiełczewski (red.), Od koncepïi ekorozwoju do ekonomii zrónnoważonego rozwoju, Wydawnictwo WSE, Białystok.

Changing Patterns. UK Government Framework for Sustainable Production and Consumption 2003, Department for Environmental, Food and Rural Affairs, London.

Dokument elektroniczny, tryb dostępu: [http://ec.europa.eu/regional_policy/themes/ Urban/audit/ index_pl.htm, data wejścia: 22.11.2013].

Dokument elektroniczny, tryb dostępu: [http://europa.eu.int/comm/eurostat/, data wejścia: 22.11.2013].

Dokument elektroniczny, tryb dostępu: [http://www. strateg. stat.gov.pl, data wejścia: 10.01.2014].

Dokument elektroniczny, tryb dostępu: [http://www.sas.zmp.poznan.pl, data wejścia: 5.01.2014]. 
Dokument elektroniczny, tryb dostępu: [http://www.stat.gov.pl/cps/rde/xbcr/gus/ PUBLurban_audit.pdf, data wejścia: 10.01.2014].

Dokument elektroniczny, tryb dostępu: [http://www.stat.gov.pl/katow/index_PLK_ HTML.htm, data wejścia: 12.01.2014].

Dokument elektroniczny, tryb dostępu: [http://www.urbanaudit.org, data wejścia: 22.11.2013].

Ekonomia zrónnoważonego rozwoju w śnietle kanonów nauki 2011, B. Poskrobko (red.), Wydawnictwo WSE, Białystok.

Fiedor B. 1996 System wskažnikeón i indeksón ekorozwoju, „Gospodarka-Środowisko Przyrodnicze-Informacja”, Biblioteka „Ekonomia i Środowisko”, Wrocław.

Finance and Accountancy for Sustainable Development - Sustainable Finance 2013, G. Borys, M. Solarz (red.), „Research Papers of Wrocław University of Economics”, no. 302.

Hellwig Z., Kania-Gospodarowicz A. 1975 Zastosowanie analisy porównawcrej w badaniach miedsynarodonych, „Z prac Zakładu Badań Statystyczno-Ekonomicznych GUS”, nr 83.

Kociszewski K. 2013 Ekologizacja polskiego rolnictwa a jego zrómnoważony rozwój w warunkach čłtonkostwa w Unii Europejskiej, Wydawnictwo Uniwersytetu Ekonomicznego we Wrocławiu, Wrocław.

Litman T. 2008 Well Measured: Developing Indicators for Comprehensive and Sustainable Transport Planning, Victoria Transport Policy Institute, Victoria, Canada.

Nitkiewicz-Jankowska A., Szromek A. R. 2014 Turystyka a zasady zrównoważonego rožroju, Maszynopis, Uniwersytet Śląski, Wydział Nauk o Ziemi, Katowice.

OECD Guidelines towards Environmentally Sustainable Transport 2002, OECD, Paris.

Opracowanie miernikón realizacji polityki ekologicznej państwa w oparcin o wskaźniki Unii Europejskiej 2004, T. Borys (red.), FK-ROE, Jelenia Góra.

Our Common Future 1987, United Nations, New York.

Pearce D., Turner R. 1990 Economics of the National Resources and the Emironment, Harvester Wheatsheaf, New York.

Polityke Transportowa Państwa na lata 2006- 2025 2005, Ministerstwo Infrastruktury, Warszawa (dokument przyjęty przez Radę Ministrów 29 czerwca 2005 roku).

Raport Analiza istniejacych danych statystycznych pod katem ich usistecżności dla określenia poziomu zrównoważonego transportu wraz z. proposycja ich rozszerzenia 2009, T. Borys (red.), Jelenia Góra-Warszawa, dokument elektroniczny, tryb dostępu: - [http://www.mir.gov.pl/ raporty, data wejścia: 22.11.2013].

Raport Koncepcja wylkoryystania wskaźników zrónnoważonego rozwoju jako wskaźników ,tta” dla sektorowych wskaźnikón ustug badanych w Systemie Analiz. Samorzadowych (SAS) 2008, T. Borys (red.), Jelenia Góra - Poznań, dokument elektroniczny, tryb dostępu: [http://www. sas.zmp.poznan.pl/raporty, data wejścia: 5.01.2014].

Rogall H. 2010 Ekonomia zrównoważonego ro:swoju - potrzęa reformy tradyojnej ekonomii, [w:] Ekonomia zrónnoważonego rozwoju, B. Poskrobko (red.), Wydawnictwo WSE, Białystok.

Skowrońska A. 2009 Rola polityki logistycznej państwa we wdrażaniu zrónnoważonego rožvoju, Wydawnictwo Uniwersytetu Ekonomicznego we Wrocławiu, Wrocław.

Stone R. 1956 Quantity and Price Indexes in National Accounts, OECD, Paris. 
Szumski W. 2008 Reflection about Sustainable Development - Is Sustainable Development fiction, utopia, illusion or szwindle, „Problems of Sustainable Development”, no. 2.

Śleszyński J. 1997 W skaźniki trwałego rozwoju, „Ekonomia i Środowisko”, nr 2.

Śleszyński J. 1998 Agregatowe wskaźniki trwałego rozwoju, „Sterowanie Ekorozwojem”, Białystok.

WHITE PAPER-European transport policy for 2010: time to decide 2001, European Commission, Luxembourg.

Wską́niki ekorozwoju 1999, T. Borys (red.), Wydawnictwo Ekonomia i Środowisko, Białystok.

Wskaźniki z̧równoważonego rožpoju 2005, T. Borys (red.), Wydawnictwo Ekonomia i Środowisko, Warszawa-Białystok.

Wsparcie w zakeresie rozwijania zestawn wskaźnikón do monitorowania narodowych strategii zrówno-

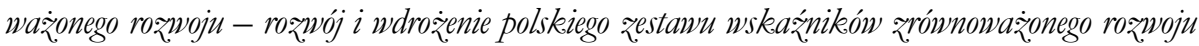
2011, Urząd Statystyczny w Katowicach, Katowice. 